\title{
Differences between National Reporting Practices and IFRS for SMEs Presentation and Disclosure Requirements: Evidence from Italy
}

\author{
Diego Valentinetti (Corresponding author) \\ Postdoctoral Research Fellow in Accounting and Business administration \\ Department of Economic studies, University “G. d'Annunzio" of Chieti-Pescara \\ Viale della Pineta, 4 - 65129 Pescara, Italy \\ Email: d.valentinetti@unich.it
}

Michele Antonio Rea

Full Professor of Accounting and Business Administration

Department of Economic Studies, University “G. d'Annunzio” of Chieti-Pescara, Italy

\author{
Caterina Basile \\ MSc in Economics and Commerce \\ Department of Economic Studies \\ University “G. d'Annunzio” of Chieti-Pescara, Viale della Pineta, 4 - 65129 Pescara, Italy
}

Received: August 03, 2016 Accepted: September 19, 2016 Published: October 03, 2016 doi:10.5296/ijafr.v6i2.9838 URL: http://dx.doi.org/10.5296/ijafr.v6i2.9838

\begin{abstract}
The aim of this paper is to assess the differences between the International Financial Reporting Standard for Small and Medium-sized Entities (IFRS for SMEs) requirements and national financial reporting practices. For this purpose, the IASB's checklist was applied to a sample of financial statements prepared in Italy by non-listed manufacturing companies. The results reveal the major differences existing in the presentation of financial statements, as well as in narrative disclosure practices in management commentary and notes. Furthermore, econometric analysis suggests that the differences are influenced by certain exploratory
\end{abstract}


factors, namely, profitability, leverage, size and parent company relationship. This study offers new insights into the roles of certain exploratory factors that are likely to influence the movement towards the application of the IFRS for SMEs.

Keywords: IFRS for SMEs; financial reporting; financial disclosure; financial statements; Italy

\section{Introduction}

In July 2009, the IASB published the International Financial Reporting Standard for Small and Medium-sized Entities - IFRS for SMEs - as a standalone standard designed to meet the needs and capabilities of small and medium-sized entities. Specifically, the standard is intended for "non-publicly accountable entities", i.e., entities that do not have their debt or equity instruments traded in public markets and that are not financial institutions (IASB, 2009). To fit both the SMEs' capabilities and user needs, the IFRS for SMEs is built on full IFRS foundations but with a number of simplifications, such as elimination of some topics not relevant for SMEs, reduction of accounting policy options allowed by full IFRS, and simplification of many recognition and measurement principles.

Since the publication of the first drafts by the IASB, many scholars have identified the IFRS for SMEs as a relevant research topic. The debate around the new standard involves several factors, including: the comments on the IASB's Discussion Paper (Evans et al., 2005) and the Exposure Draft 'IFRS for Small and Medium-Sized Entities' (Di Pietra et al., 2008); the different perspectives of acceptance among users, preparers and European Countries (Quagli \& Paoloni, 2012); and the factors influencing countries' adoption of the IFRS for SMEs (Kaya \& Koch, 2015). A number of contributions have referred to country-specific perspectives, such as those of the Czech Republic (Albu et al., 2013; Nerudova \& Bohusova, 2008; Pàlka \& Svitàkovà, 2011), Estonia (Alver et al., 2014), Germany (Eierle \& Haller, 2009; Kreipl et al., 2014), Ghana (Aboagye-Otchere \& Agbeibor, 2012), Greece (Mandilas et al., 2010) Italy (Baldarelli et al., 2007; Cisi, 2008), the Netherlands (Litjens et al., 2012), Romania (Albu et al., 2010; Gîrbină et al., 2012), South Africa (Schutte \& Buys, 2011; Stainbank, 2008; van Wyk \& Rossouw, 2009), Spain (Milanés Montero et al., 2011), Turkey (Arsoy et al., 2007; Atik, 2010; Kiliç et al., 2016; Turegun \& Kaya, 2014), the United Arab Emirates (Kumar, 2014) and the USA (Jermakowicz \& Epstein, 2010). Nevertheless, despite some prior studies having analysed similarities and differences between the IFRS for SMEs and certain accounting settings - namely, the EU Accounting Directives (EFRAG, 2010), local GAAP (Albu et al., 2010; Buculescu \& Velicescu, 2014; Cisi, 2008; EFAA, 2010; Girbina et al., 2012), and full IFRS as well (Jerman \& Ivankovič, 2011; Pacter, 2009; Pacter, 2013; PWC, 2009;) -, there have been no studies considering the difference between the IFRS for SMEs requirements and current local GAAP-based practices, i.e., financial statement content. This study attempts to fill this gap by making a comprehensive comparison of the IFRS for SMEs presentation and disclosure requirements with the Italian financial reporting practices. Such an approach allows for the identification of critical areas that would require significant changes to accounting practices of firms if the standard is applied at 
national level. Additionally, the empirical estimation on the potential factors influencing the differences suggests that a) less profitable firms, b) smaller firms, and c) firms not included in their parents' IFRS-compliant consolidated financial statements are less suitable than others for application of the IFRS for SMEs.

The contribution of this study to the literature is twofold. First, the results confirm the significant associations between disclosure level and certain corporate attributes widely used in prior research - i.e., profitability, leverage and size - in a new setting, namely the IFRS for SMEs and domestic practices. The negative and significant influence of leverage on disclosure level, moreover, reflects the different recipients of accounting models: although the IFRS for SMEs is mainly intended to meet the needs of a broad range of users, the Italian national accounting model is mainly creditor-oriented. Such evidence also contributes to research on the protection of investors and creditors by different legal systems, namely common law and civil law (Houqe et al., 2012; Jaggi \& Low, 2000; La Porta et al., 1998; La Porta et al., 2000). Second, we introduce a new proxy to measure the relationship with the parent company, that is, the inclusion of a firm in a consolidated financial statement prepared under the IFRS. The results support our expectations because some information required by parent companies for consolidated accounts influences the disclosures in SMEs' individual annual reports.

The remainder of this paper is structured as follows. The next section provides a brief comparison of the IFRS for SMEs and the Italian accounting regulations for non-listed companies, followed by the research aim and hypothesis development. Sections 3 and 4 present the research methods and results, respectively. Conclusions are outlined in the final section.

\section{Regulatory and Institutional Background}

\subsection{IFRS for SMEs vs. Italian SMEs' Reporting Environment: Overview and Major Differences}

The IFRS for SMEs is a separate standard intended to be applied to the general purpose financial statements of non-publicly accountable entities. To generate a simplified version of the IFRS, the IASB developed the IFRS for SMEs by: a) extracting the fundamental concepts from its framework and the principles and related mandatory guidance from full IFRSs (including Interpretations); and b) considering the modifications that were appropriate on the basis of users' needs and cost-benefit considerations (IASB, 2009). The standard contains a number of simplifications, incorporations and omissions, compared to the full IFRS. The main simplifications concern many recognition and measurement principles, along with a reduction in the accounting policy options allowed by the full IFRS. Some issues relevant to SMEs but not addressed in the full IFRS (i.e., combined financial statements, original issues of shares or other equity instruments, sales of options, rights and warrants, and capitalisation or bonus issues of shares and share splits) have been incorporated. Finally, the following topics were omitted because they were not expected to be relevant for the majority of SMEs: earnings per share, interim financial reporting, segment reporting, and special accounting for assets held for sale. The structure of the standard consists of 35 sections, each of which is 


\section{Macrothink \\ International Journal of Accounting and Financial Reporting

derived from the full IFRS (see Table 1).

Table 1. IFRS for SMEs sections and relative primary sources in the full IFRS

\begin{tabular}{|c|c|c|}
\hline & Section in the IFRS for SMEs & Sources \\
\hline & Preface & $\begin{array}{l}\text { Preface to International Financial } \\
\text { Reporting Standards }\end{array}$ \\
\hline 1 & Small and Medium-sized Entities & - \\
\hline 2 & Concepts and Pervasive Principles & $\begin{array}{l}\text { IASB Framework, IAS } 1 \text { Presentation of } \\
\text { Financial Statements as revised in } 2007\end{array}$ \\
\hline 3 & Financial Statement Presentation & IAS 1 Presentation of financial statement \\
\hline 4 & Statement of Financial Position & IAS 1 Presentation of financial statement \\
\hline 5 & $\begin{array}{l}\text { Statement of Comprehensive Income } \\
\text { and Income Statement }\end{array}$ & IAS 1 Presentation of financial statement \\
\hline 6 & $\begin{array}{l}\text { Statement of Changes in Equity and } \\
\text { Statement of Comprehensive Income } \\
\text { and Retained Earnings }\end{array}$ & IAS 1 Presentation of financial statement \\
\hline 7 & Statement of Cash Flows & IAS 7 Statement of Cash Flows \\
\hline 8 & Notes to the Financial Statements & IAS 1 Presentation of financial statement \\
\hline 9 & $\begin{array}{l}\text { Consolidated and Separate Financial } \\
\text { Statements }\end{array}$ & $\begin{array}{l}\text { IAS } 27 \text { Consolidated and Separate } \\
\text { Financial Statements as amended in } 2008\end{array}$ \\
\hline 10 & $\begin{array}{l}\text { Accounting Policies, Estimates and } \\
\text { Errors }\end{array}$ & $\begin{array}{l}\text { IAS } 8 \text { Accounting Policies, Changes in } \\
\text { Accounting Estimates and Errors }\end{array}$ \\
\hline $\begin{array}{l}11 \text { and } \\
12\end{array}$ & $\begin{array}{l}\text { Basic Financial Instruments and Other } \\
\text { Financial Instruments Issues }\end{array}$ & \begin{tabular}{lcr} 
IAS $\quad 32$ & Financial & \multicolumn{2}{c}{ Instruments: } \\
Presentation, & IAS 39 & Financial \\
Instruments: & Recognition & and \\
Measurement, & IFRS 7 & Financial \\
Instruments: Disclosures & &
\end{tabular} \\
\hline 13 & Inventories & IAS 2 Inventories \\
\hline
\end{tabular}




\begin{tabular}{|c|c|c|}
\hline 14 & Investments in Associates & IAS 28 Investments in Associates \\
\hline 15 & Investments in Joint Ventures & IAS 31 Interests in Joint Ventures \\
\hline 16 & Investment Property & IAS 40 Investment Property \\
\hline 17 & Property, Plant and Equipment & IAS 16 Property, Plant and Equipment \\
\hline 18 & Intangible Assets other than Goodwill & IAS 38 Intangible Assets \\
\hline 19 & Business Combinations and Goodwill & $\begin{array}{l}\text { IFRS } 3 \text { Business Combinations as } \\
\text { revised in } 2008\end{array}$ \\
\hline 20 & Leases & IAS 17 Leases \\
\hline 21 & Provisions and Contingencies & $\begin{array}{l}\text { IAS } 37 \text { Provisions, Contingent Liabilities } \\
\text { and Contingent Assets }\end{array}$ \\
\hline 22 & Liabilities and Equity & IAS 1 , IAS 32 \\
\hline 23 & Revenue & $\begin{array}{l}\text { IAS } 11 \text { Construction Contracts, IAS } 18 \\
\text { Revenue }\end{array}$ \\
\hline 24 & Government Grants & $\begin{array}{l}\text { IAS } 20 \text { Accounting for Government } \\
\text { Grants and Disclosure of Government } \\
\text { Assistance }\end{array}$ \\
\hline 25 & Borrowing Costs & IAS 23 Borrowing Costs \\
\hline 26 & Share-based Payment & IFRS 2 Share-based Payment \\
\hline 27 & Impairment of Assets & IAS 2, IAS 36 Impairment of Assets \\
\hline 28 & Employee Benefits & IAS 19 Employee Benefits \\
\hline 29 & Income Tax & IAS 12 Income Taxes \\
\hline 30 & Foreign Currency Translation & $\begin{array}{l}\text { IAS } 21 \text { The Effects of Changes in } \\
\text { Foreign Exchange Rates }\end{array}$ \\
\hline 31 & Hyperinflation & $\begin{array}{l}\text { IAS } 29 \text { Financial Reporting in } \\
\text { Hyperinflationary Economies }\end{array}$ \\
\hline
\end{tabular}




\begin{tabular}{|l|l|l|}
\hline 32 & $\begin{array}{l}\text { Events after the End of the Reporting } \\
\text { Period }\end{array}$ & IAS 10 Events after the Reporting Period \\
\hline 33 & Related Party Disclosures & IAS 24 Related Party Disclosures \\
\hline 34 & Specialised Activities & $\begin{array}{l}\text { IAS 41 Agriculture, IFRS 6 Exploration } \\
\text { for and Evaluation of Mineral Resources }\end{array}$ \\
\hline 35 & $\begin{array}{l}\text { Transition to the IFRS for SMEs } \\
\text { IFRS 1 First-time Adoption of } \\
\text { International Financial Reporting } \\
\text { Standards }\end{array}$
\end{tabular}

Source: IASB, IFRS for SMEs - Derivation table, London, UK, 2009, pp. 229-230

The Italian financial reporting framework is based on two alternative models. Indeed, until 2005, all Italian companies were mandated to prepare their financial statements according to the national civil model. After the release of EU Regulation 1606/2002, the Italian government introduced the IAS/IFRS model through Legislative Decree 38/2005 for the following entities: listed companies, banks, insurance companies and other financial entities subject to the supervision of the Bank of Italy. Such entities must prepare their consolidated and individual accounts (as of 2005 and 2006, respectively) in compliance with the IAS/IFRS. The remaining companies must apply the Italian national model, unless they voluntarily decide to follow the IAS/IFRS. Because these companies are mainly SMEs, the focus of this study is on the national accounting model, which is strictly based on national regulation. In particular, such a model is primarily regulated by the Italian Civil Code's articles 2423 to 2435-bis, within the section entitled "On annual accounts". Such regulation stems from a set of national accounting laws pursuant to the European directives on accounting harmonisation. Additionally, the Italian GAAP issued by the Italian Organisation of Accounting (OIC, Organismo Italiano di Contabilità), which is the official accounting standard setter in Italy, interprets and integrates the accounting requirements set by national laws.

A comparison between the IFRS for SMEs and Italian GAAP model is useful prior to introducing the empirical research. The main difference concerns the legal system that underpins each model. The former, on the one hand, reflects the common law legal system, whereas the latter, on the other hand, is based on the civil law system. The prevalent accounting literature has emphasised the role of private accounting practices in common law systems, whereas strong political influence on accounting has been recognised in civil law systems because governments establish and enforce national accounting standards (Ball et al., 2000; Jaggi \& Low, 2000; La Porta et al., 1998; Salter \& Doupnik, 1992; Soderstrom \& Sun, 2007).

Considering the nature and origin of regulatory bodies, the IFRS for SMEs represents the output of a professional entity, the IASB, formed by an independent group of experts with an 
appropriate mix of practical experience in setting accounting standards. The Italian domestic model, conversely, is prominently based on a set of governmental laws, with a high degree of formalisation. OIC professional principles, therefore, are issued as secondary sources to integrate and interpret the legal provisions.

Another difference between the two approaches concerns the recipients of annual reports. According to the IFRS for SMEs' Concept and Pervasive Principle 2.2, "The objective of financial statements of a small or medium-sized entity is to provide information about the financial position, performance and cash flows of the entity that is useful for economic decision-making by a broad range of users who are not in a position to demand reports tailored to meet their particular information needs". The Italian framework, in contrast, considers the creditors to be the main recipients of financial statements. This consideration reflects the Italian SMEs environment, which is characterised by a concentrated ownership structure and high dependency on banking institutions, which represent the main source of financing. Hence, regulated financial reporting is mainly creditor-oriented.

The two financial reporting models also differ in their basis of accounting. As a consequence of the divergence in their users' orientations, the IFRS for SMEs is closer to the common law system, in which accrual concepts dominate to emphasise the financial position and performance of entities. The Italian model, conversely, has a high degree of prudence aiming at protecting creditors' positions. Therefore, the recognition and measurement of accounting items are entirely based on historical costs.

Finally, it is worth considering the different influences of tax regulation. On the one hand, the IFRS for SMEs recognises that tax laws are specific to each jurisdiction, and the objectives of general purpose financial reports differ from the objectives of reporting taxable profit . Hence, the standard is not influenced by fiscal regulation. The Italian accounting model, on the other hand, is strongly influenced by tax regulation, which is defined by the same national governmental authority. This influence, moreover, is highly related to SMEs' reality because owner-managers often produce financial statements only for tax or other governmental authorities (IASB, 2009).

Table 2 summarises the differences discussed and their implications for accounting.

Table 2. Key differences between IFRS for SMEs and the Italian domestic model

\begin{tabular}{|l|l|l|l|l|}
\hline \multirow{2}{*}{ Conceptual } & \multicolumn{2}{|l|}{ IFRS for SMES } & \multicolumn{2}{l|}{ Italian GAAP model } \\
\cline { 2 - 6 } issue & $\begin{array}{l}\text { Theoretical } \\
\text { orientation }\end{array}$ & $\begin{array}{l}\text { Implications for } \\
\text { accounting }\end{array}$ & $\begin{array}{l}\text { Theoretical } \\
\text { orientation }\end{array}$ & $\begin{array}{l}\text { Implications } \\
\text { accounting }\end{array}$ \\
\hline Legal system & $\begin{array}{l}\text { Common } \\
\text { law system }\end{array}$ & $\begin{array}{l}\text { Accounting practices } \\
\text { are determined } \\
\text { primarily in the } \\
\text { private sector. }\end{array}$ & $\begin{array}{l}\text { Civil law } \\
\text { system }\end{array}$ & $\begin{array}{l}\text { Strong political } \\
\text { influence on } \\
\text { accounting. } \\
\text { Governments } \\
\text { establish and enforce }\end{array}$ \\
\hline
\end{tabular}




\begin{tabular}{|c|c|c|c|c|}
\hline & & & & $\begin{array}{l}\text { national accounting } \\
\text { standards. }\end{array}$ \\
\hline $\begin{array}{l}\text { Nature and } \\
\text { origin of } \\
\text { regulatory } \\
\text { body }\end{array}$ & $\begin{array}{l}\text { Professional } \\
\text { (IASB) }\end{array}$ & $\begin{array}{l}\text { Private-sector bodies } \\
\text { codify generally } \\
\text { accepted accounting } \\
\text { rules. Standards arise } \\
\text { in an accounting } \\
\text { market, not in } \\
\text { government. }\end{array}$ & $\begin{array}{l}\text { Government } \\
\text { al }\end{array}$ & $\begin{array}{l}\text { EU Directives- } \\
\text { compliant } \\
\text { governmental laws } \\
\text { define the accounting } \\
\text { model. Professional } \\
\text { principles are issued } \\
\text { as secondary source } \\
\text { to integrate and } \\
\text { interpret legal } \\
\text { provisions. }\end{array}$ \\
\hline $\begin{array}{l}\text { Main } \\
\text { recipient of } \\
\text { annual } \\
\text { reports }\end{array}$ & $\begin{array}{l}\text { Broad range } \\
\text { of users }\end{array}$ & $\begin{array}{l}\text { The objective of } \\
\text { financial statements is } \\
\text { to provide } \\
\text { information that is } \\
\text { useful to users in their } \\
\text { decision-making } \\
\text { processes. }\end{array}$ & Creditors & $\begin{array}{l}\text { Creditors are the } \\
\text { main recipients of } \\
\text { financial statements } \\
\text { because the Italian } \\
\text { SMEs environment is } \\
\text { characterised by a } \\
\text { concentrated strong } \\
\text { ownership structure } \\
\text { and on } \\
\text { dependency institutions, } \\
\text { banking the } \\
\text { which represent ource of } \\
\text { main souncing. } \\
\text { financin }\end{array}$ \\
\hline $\begin{array}{l}\text { Basis of } \\
\text { accounting }\end{array}$ & $\begin{array}{l}\text { Accrual } \\
\text { concepts } \\
\text { dominate }\end{array}$ & $\begin{array}{l}\text { Accrual concepts } \\
\text { dominate in to } \\
\text { emphasise the } \\
\text { financial position and } \\
\text { performance of } \\
\text { entities. }\end{array}$ & $\begin{array}{l}\text { Prudence } \\
\text { concept } \\
\text { dominates }\end{array}$ & $\begin{array}{l}\text { Recognition and } \\
\text { measurement } \\
\text { accounting items are } \\
\text { entirely based on } \\
\text { historical cost to } \\
\text { protect creditors' } \\
\text { positions. }\end{array}$ \\
\hline $\begin{array}{l}\text { Tax } \\
\text { regulation } \\
\text { influence }\end{array}$ & Absent & $\begin{array}{l}\text { The standard is not } \\
\text { influenced by fiscal } \\
\text { regulation because } \\
\text { tax laws are specific } \\
\text { to each jurisdiction, } \\
\text { and the objectives of }\end{array}$ & Strong & $\begin{array}{l}\text { Tax regulation is } \\
\text { defined by the } \\
\text { national } \\
\text { governmental } \\
\text { authority. } \\
\text { Additionally, SMEs' }\end{array}$ \\
\hline
\end{tabular}




\begin{tabular}{|l}
\hline Matrothin \\
\hline Instute
\end{tabular}

Source consulted: Ball et al. (2000); Dunne et al. (2008); IASB (2009); Wallace \& Naser (1995)

\subsection{Research Aim and Hypothesis Development}

The aim of this paper is to assess the differences between Italian SMEs' financial reports and the IFRS for SMEs presentation and disclosure requirements. It should be noted that this study aims to compare the IASB's IFRS for SMEs financial statement model and current Italian regulated reporting practices, whereas previous studies have focused only to the differences with other accounting standards. The European Financial Reporting Advisory Group, in responding to a request of the European Commission, identified a number of incompatibilities between the requirements of the IFRS for SMEs and those of the EU Accounting Directives (EFRAG, 2010). The European Federation of Accountants and Auditors for small and medium-sized enterprises investigated the differences existing between the IFRS for SMEs and the national GAAP applied to nine EU member states (EFAA, 2010). Similarly, other studies analysed the convergence between IFRS for SMEs and accounting regulations in Czech Republic (Strohual et al., 2009) and Romania (Albu et al., 2010; Buculescu and Velicescu, 2014; Girbina et al., 2012;). However, as noted by Nobes (2009), comparisons between domestic and international standards should consider not only differences in the rules (de jure difference), but also differences to practices (de facto differences). In this context, our study aims to extend the extant literature by considering the differences between the IFRS for SMEs requirements and domestic reporting practices (Figure 1). Such a comparison seeks to emphasise critical areas, in terms of major differences in presentation and disclosure, which private companies should address if the IFRS for SMEs is adopted at the national level. Empirical evidence drawn from the specific context of Italy should be relevant in other countries with similar characteristics in their national accounting systems, including: a) accounting regulations based on a civil law legal system; and b) a financial statement model based on European accounting harmonisation. 


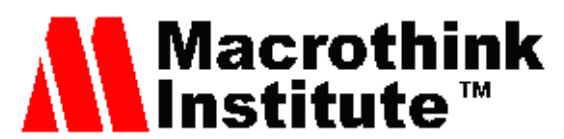

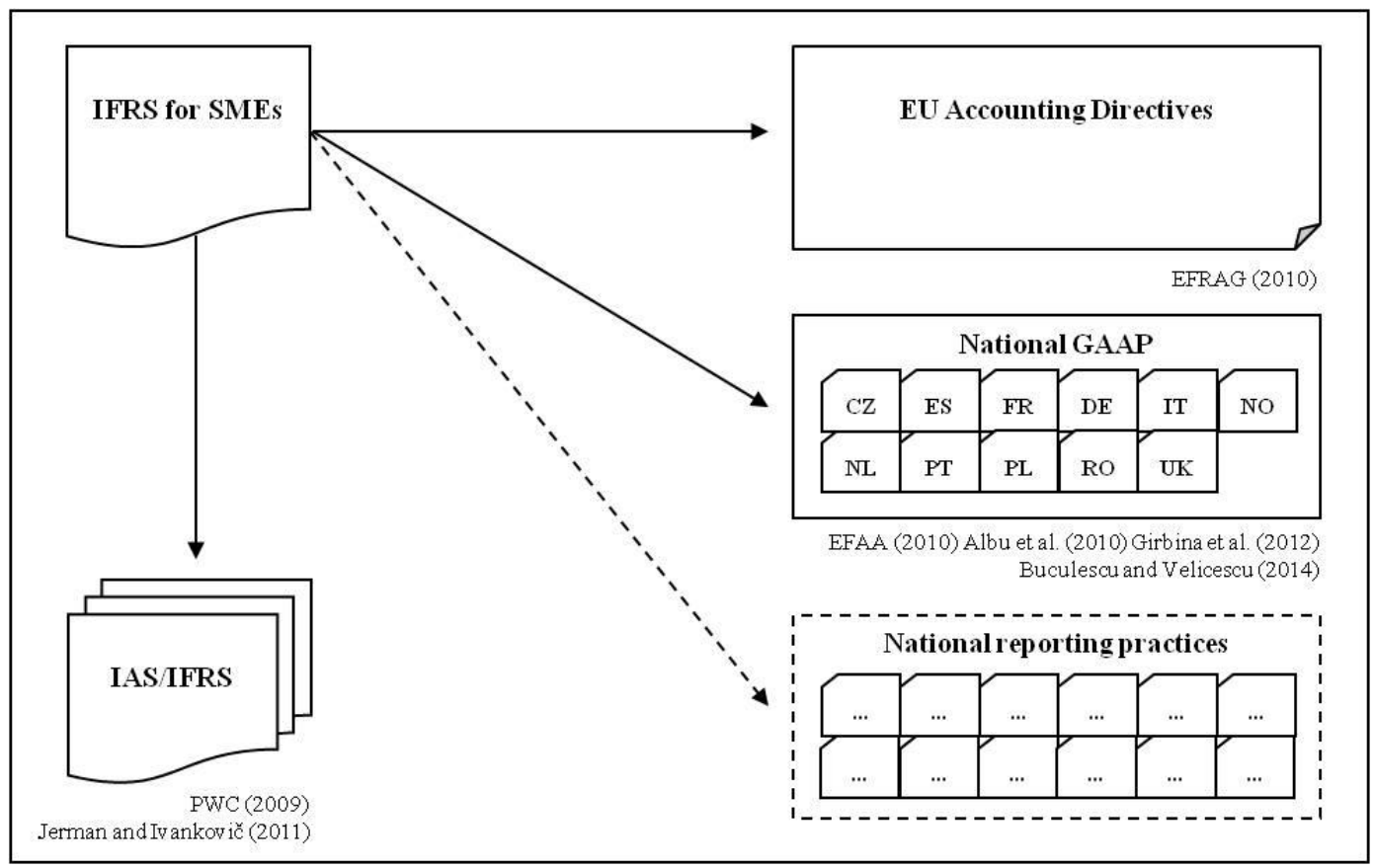

Figure 1. Research on differences between IFRS for SMEs and other accounting settings

Furthermore, the expected differences in presentation and disclosure can be investigated to assess the potential impacts of certain significant factors of the companies. For this purpose, we refer to the international literature investigating the associations between firms' characteristics and different disclosure levels in annual reports. The meta-analysis conducted by Ahmed and Courtis (1999) has reviewed the underlying causes of variations in the results of disclosure studies and has noted several corporate characteristics. According to their analysis, the most frequent of these attributes include corporate size, listing status, capital structure (leverage), profitability, and size of the reporting entity's auditing firm. Considering the exploratory nature of our study, we relied on these attributes to formulate our research hypotheses (listing status is excluded because listed companies are mandated to apply the IAS/IFRS for their financial accounts).

Size is the corporate characteristic most often used to explain different levels of disclosure. A consistent positive association reported in the literature suggests that larger companies show better disclosure practices. The main reason is that larger firms usually attract a large following of suppliers, customers and analysts; thus, greater demand exists for more information about their activities (Wallace \& Naser, 1995). Within the SMEs environment, it has been noted that the costs of preparing and distributing highly detailed annual reports might be too burdensome for smaller firms or might even be detrimental to their competitiveness (Buzby, 1975; Singhvi \& Desai, 1971). This is even more relevant when considering that the IFRS for SMEs is based on a more complex set of accounting standards, i.e. the IAS/IFRS, considered too complicated to adopt by small companies (Larson \& Street, 2004). Additionally, the recent survey by Eierle \& Haller (2009) has shown that corporate size influences the suitability of the IFRS for SMEs, notably with regards to the structure of entities, their international exposure and, to a large extent, the relevance of particular 
accounting issues. These arguments lead to our first research hypothesis:

$\mathbf{H}_{1}$ : Firm size is associated with the differences between national reporting practices and the IFRS for SMEs presentation and disclosure requirements.

Following the literature on financial disclosure (Buzby, 1975; Cooke, 1989; Singhvi \& Desai, 1971; Wallace et al., 1994; Wallace \& Naser, 1995), we measure corporate size on the basis of the value of total assets.

Leverage is also studied as a potential determinant of disclosure level, although the literature has provided a mix of significant and non-significant results. A positive association would be reasonable because highly leveraged firms seek to reduce monitoring costs by disclosing more information in their annual reports (Jensen \& Meckling, 1976). However, such a prediction should consider the nature of this study. On the one hand, accounting information under the IFRS for SMEs is designed to meet the needs of different users in their decisionmaking processes, whereas on the other hand, the Italian GAAP model identifies creditors as the main recipients of financial statements. Considering this issue, more leveraged firms' reporting practices should fully reflect national accounting requirements to satisfy their creditors. Such practices, reasonably, may be too restrictive to satisfy different users of financial reports, as pursued by the IFRS for SMEs. Hence, the second research hypothesis is formulated to detect any significant association:

$\mathbf{H}_{2}$ : Firm leverage is associated with the differences between national reporting practices and the IFRS for SMEs presentation and disclosure requirements.

Because the Italian SMEs' financial structure heavily relies on debts, we use Liabilities/Total assets as a proxy to measure financial leverage, consistently with previous studies conducted in civil law countries (Chow \& Wong-Boren, 1987; Patton \& Zelenka, 1997; Raffournier, 1995).

Profitability is often used to test different disclosure levels. Higher performance would cause managers to disclose detailed information, thus providing assurance about its positions and compensation (Singhvi \& Desai, 1971). Hence, annual reports are used by firms to signal their good performance to stakeholders, which leads to our third research hypothesis:

$\mathbf{H}_{3}$ : Firm profitability is associated with the differences between national reporting practices and the IFRS for SMEs presentation and disclosure requirements.

To reduce the effect of taxation, we measure the profitability of firms as Earnings before taxes/Total sales (Wallace et al., 1994; Wallace \& Naser, 1995).

Audit firm size ends the list of the most frequent attributes explaining corporate financial disclosure in the literature. Larger audit firms would influence reporting practices in terms of both the quantity and quality of disclosed information, although empirical support for such associations has not been systematically found. However, considering the SMEs' environment, international audit firms (e.g., the "Big4") are expected to bring enhanced credibility to financial reports, compared to domestic auditors (Patton \& Zelenka, 1997). Accordingly, our fourth research hypothesis is as follows: 


\section{Macrothink}

International Journal of Accounting and Financial Reporting

$\mathbf{H}_{4}$ : Audit firm size is associated with the differences between national reporting practices and the IFRS for SMEs presentation and disclosure requirements.

A dummy variable distinguishes SMEs audited by larger international audit firms (BIG4=1) from those audited by other auditors (BIG4=0).

In addition to the most relevant factors related to financial reporting and disclosure, we also consider the firm's relationship with its parent company. Cooke (1989) has recognised the difficulty of predicting the direction of any relationship. On the one hand, companies with more subsidiaries will have more sophisticated reporting systems that will enable greater disclosure overall in their corporate annual reports. On the other hand, those companies might be able to hide information by aggregation. Owusu-Ansah (1998) has argued for a positive association because affiliates of multinational companies are likely to have more sophisticated financial reporting systems that facilitate greater disclosure in their annual reports than other local non-affiliated companies. El-Gazzar et al. (1999) found a number of factors influencing the multinational firms' compliance with IAS. Such arguments seem relevant to the SMEs' context because smaller firms are often affiliated with larger companies. However, considering the nature of this study, we introduce a new proxy not yet used in prior studies: the inclusion of a firm in a consolidated financial statement prepared under the IFRS. Our expectation is that such firms could transfer some information, required by their parent companies for the preparation of IFRS-compliant consolidated accounts, into their individual annual reports. Hence, the fifth research hypothesis is defined as follows:

H5: Parent company relationships are associated with the differences between national reporting practices and the IFRS for SMEs presentation and disclosure requirements.

The dummy variable IFRS_GROUP has been defined to identify SMEs included in IFRSbased consolidated annual reports $(=1)$ from others $(=0)$.

Table 3 summarises the explanatory factors investigated by means of the hypotheses, along with their operationalization and expected signs. 


\section{Macrothink}

International Journal of Accounting and Financial Reporting

Table 3. Explanatory factors of the analysis and expected signs

\begin{tabular}{|c|c|c|c|c|}
\hline Hypothesis & $\begin{array}{l}\text { Factor } \\
\text { investigated }\end{array}$ & Variable & Notation & $\begin{array}{l}\text { Expec } \\
\text { ted } \\
\text { sign }\end{array}$ \\
\hline $\mathrm{H} 1$ & Size & Total assets & ASSETS & - \\
\hline $\mathrm{H} 2$ & Leverage & Liabilities/Total assets & LEV & ? \\
\hline $\mathrm{H} 3$ & Profitability & Earnings before taxes/Total sales & EBT/SALES & - \\
\hline $\mathrm{H} 4$ & Audit firm size & $\begin{array}{l}1 \text { audited by Big4 } \\
0 \text { otherwise }\end{array}$ & BIG4 & ? \\
\hline H5 & $\begin{array}{l}\text { Parent } \\
\text { company } \\
\text { relationship }\end{array}$ & $\begin{array}{l}1 \quad \text { consolidated in parent } \\
\text { company's IFRS annual report } \\
0 \text { not consolidated }\end{array}$ & IFRS_GROUP & - \\
\hline
\end{tabular}

\section{Research design}

\subsection{Research instrument: the Presentation and Disclosure Checklist}

To accomplish the research objective, a presentation and disclosure checklist was used to assess the extent of differences between Italian GAAP-based financial statements and the IFRS for SMEs requirements. The checklist is provided by the IASB as an annex of the standard, and it addresses both presentation and disclosures requirements in the IFRS for SMEs. Specifically, its structure is based on the sections of the standard containing tailoring and detailed questions that assist in determining whether the presentation and disclosure requirements of each section are met ${ }^{1}$. Sections $3-7$ prescribe the basis for the presentation of

\footnotetext{
${ }^{1}$ Some sections are excluded from the analysis for several reasons. First, Sections 1 Small and Medium-Sized Entities, 2 Concepts and Pervasive Principles and 22 Liabilities and Equity are not included by the checklist itself, because no presentation or disclosure requirements are included in these sections of the standard. Second, Sections 9 Consolidated and Separate Financial Statements, 19 Business Combinations and Goodwill and 33 Related Party Disclosures are excluded because this study focuses on individual annual reports. Third, Section 28 Employee Benefits is excluded because of the great difficulties in comparing the TFRL national regulation ("Trattamento di Fine Rapporto di Lavoro") and the IASB's employee benefits approach. Fourth, Sections 31 Hyperinflation and Section 34 Specialised Activities are beyond the scope of this study. Finally, Section 35 Transition to the IFRS for SMEs is excluded because this paper is not intended to investigate a first-time adoption of the IFRS for SMEs.
} 


\section{Ml Macrothink}

International Journal of Accounting and Financial Reporting ISSN 2162-3082 2016, Vol. 6, No. 2

general purpose financial statements and require the presentation of some specific line items in the statement of financial position, statement of comprehensive income, statement of changes in equity and statement of cash flows. Sections 8-35 address the information to be presented in the notes to the financial statements and how to present it; such information concerns the following issues: accounting policies, estimates and errors; financial instruments; inventories; investments; tangible and intangible assets; leases; provisions and contingencies; revenue and government grants; borrowing costs; share-based payments; impairment of assets; income tax; foreign currency translation; and events after the end of the reporting period. In most cases, the IFRS does not specify whether a disclosure should be made within a financial statement or in the notes. In several cases, however, disclosures are expressly required to be in a financial statement; these cases are identified in the checklist (IASB, 2009).

To apply a rigorous methodology to the data collection, two issues were addressed. The first issue concerns the validity of the research instrument, identified as the ability to measure adequately the concepts of interest. In this regard, the checklist itself should ensure the maximum validity of the disclosure items, inasmuch as it has been developed by the same entity (i.e., the IASB) involved in the preparation of the standard that includes those items. However, a careful preliminary analysis of the checklist was necessary to eliminate some items that actually explain, but do not require, specific disclosures. The second issue is the reliability of the research instrument, which concerns the accuracy in measuring the concepts under investigation. To address this issue, the checklist was first tested on 30 financial statements and then was applied to the overall sample of firms. Each annual report was scored by a junior researcher, under the supervision of two senior researchers. In cases of uncertainty about specific scores, careful consultation among the three researchers was undertaken to reach a final agreed-upon score.

\subsection{Sample and Data}

The checklist was applied to a sample of 105 annual reports prepared under Italian GAAP as of 31 December 2013. To analyse a homogeneous set of annual reports as much as possible, this study focused on the manufacturing sector, which represents the most representative sector of private companies in Italy (ATECO Section C "Manufacturing activities"; Divisions 10-33). Simplified and consolidated annual accounts were excluded. The reports were downloaded from the Bureau van Dijk's AIDA database.

The data collection was performed as follows. Each annual report was carefully scrutinised to assess the presence of each presentation and disclosure requirement included within the checklist. To assist in the data collection and analysis, Deloitte's IFRS for SMEs Presentation and Disclosure Checklist 2013 was used because it provides, in Microsoft Excel format, the presentation and disclosure requirements presented in the IASB's IFRS for SMEs. Figure 2 shows an excerpt of the checklist. 


\section{MInstitute Macrothink $^{m}$}

International Journal of Accounting and Financial Reporting

ISSN 2162-3082

2016, Vol. 6, No. 2

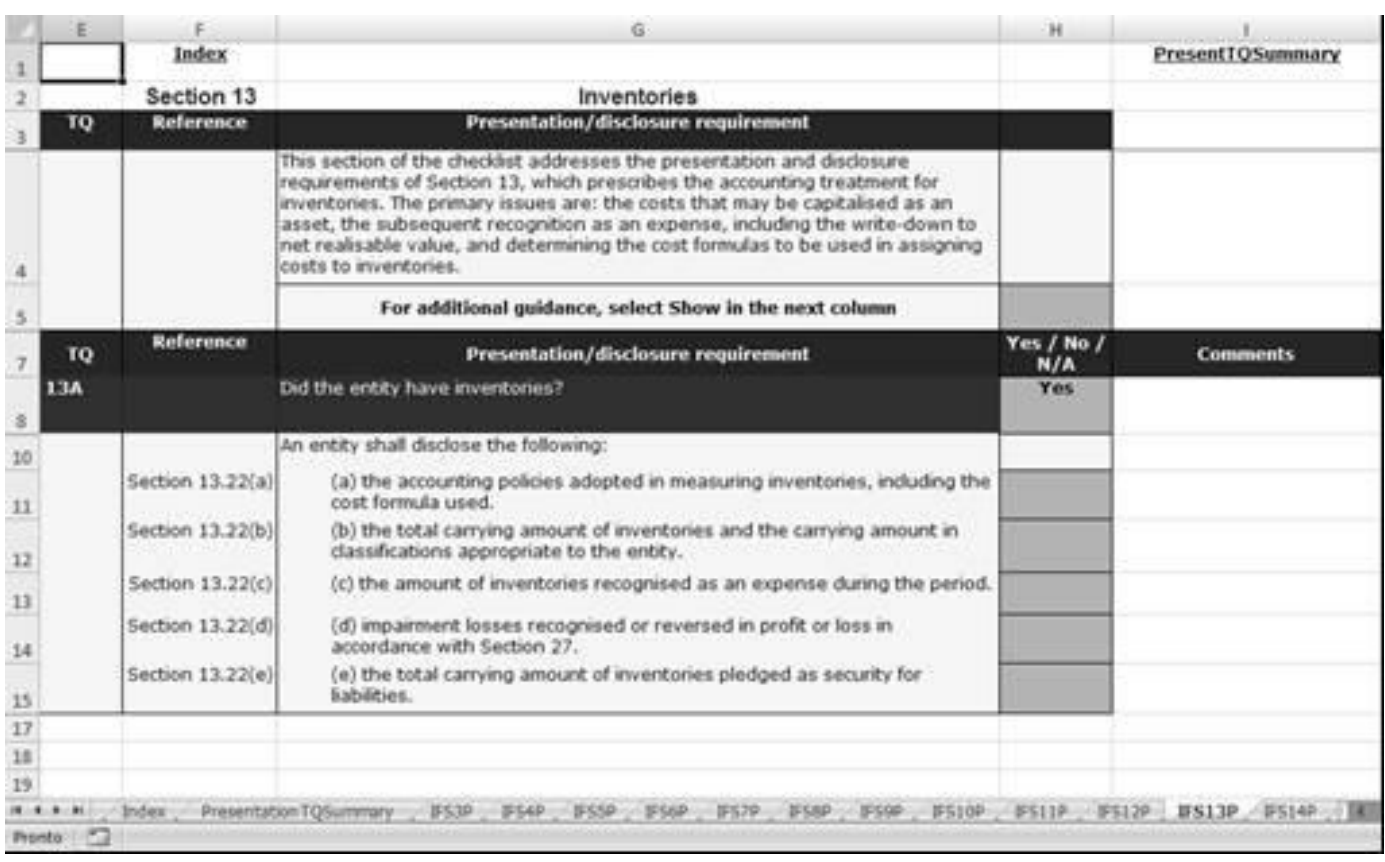

Figure 2. Excerpt from the Presentation and Disclosure Checklist - Section 13 Inventories

Source: Deloitte, IFRS for SMEs Presentation and Disclosure Checklist 2013

If required information was retrieved in a report, the researcher assigned a score of 1 , otherwise, a score of 0 was assigned. However, it should be specified that such an operation is not merely an assessment of the presence/absence of information because a company's non-disclosure of an item can have different interpretations. On the one hand, a company simply might not have any particular accounting issue and thus has not commented on it; on the other hand, a stricter interpretation is that a company is not aligned with a disclosure requirement, (Tower et al., 1999). Hence, the appropriate score is N/A - i.e., "not applicable" - or 0, respectively. An example might better clarify this issue. If the researcher does not retrieve the accounting policies adopted for measuring inventories, he/she should verify whether that entity has effectively no inventories reported on its financial statements. If so, it is not possible to assign the score of 0 - i.e., the firm would be penalised - but it is appropriate to indicate such a requirement on the checklist as N/A because it is not relevant. Alternatively, if the researcher verifies that the inventories are accounted for in the statement of financial position, but no information about the accounting policies is disclosed in the notes, then the score would be 0 because the firm is actually not aligned with that requirement. Such a procedure requires a feed-forward approach, for which the researcher might be required to retrieve information located in different parts of the annual report and then to return to the checklist to answer a single question. In other words, it is not sufficient to focus on a single part of the report depending on the specific requirements of the checklist, but the researcher must read the entire report to retrieve pieces of information disclosed elsewhere - e.g., in the management commentary or in the notes. This approach is considered by the prior relevant literature to be an appropriate method for addressing this issue, which is not to penalise a firm for non-disclosure if the item is not relevant to the firm (Al-Akra et al., 2010; Cooke, 1992; Street \& Bryant, 2000; Street \& Gray, 2002;). 


\section{Macrothink}

International Journal of Accounting and Financial Reporting

ISSN 2162-3082

2016, Vol. 6, No. 2

To analyse the collected data, a Presentation and Disclosure Index (PDI) was defined, following Cooke (1992). The index was defined by dividing the total number of required disclosures, provided by the companies, by the number of applicable disclosures, as follows:

$P D I_{j}=\frac{\sum_{i=1}^{n j} x_{i j}}{n_{j}}$

where

$\mathrm{n}_{\mathrm{j}}=$ number of relevant items for $\mathrm{j}^{\text {th }}$ firm, and

$\mathrm{x}_{\mathrm{ij}}=1$ if $\mathrm{i}^{\text {th }}$ item disclosed and 0 otherwise.

Hence, the index explains the total number of items disclosed by company $\mathrm{j}^{\text {th }}$ (and required by the IFRS for SMEs), which is divided by the total number of applicable items of the checklist so that $0 \leq \mathrm{PDIj} \leq 1$. The higher the index, the higher the level of adherence to the IFRS for SMEs presentation and disclosure requirements, and viceversa. However, for the purpose of this study to focus on differences between the practices and the standard, we applied the following formula:

$\triangle P D I_{j}=1-P D I_{j}$

The new variable $\triangle \mathrm{PDIj}$ measures the extent of difference between IFRS for SMEs requirements and reporting practices of each firm: the higher the value, the greater the extent of distance. In agreement with the general structure of the checklist, we consider $\triangle \mathrm{PDIj}$ as the main variable, which is further broken down in two sub-variables, $\Delta \mathrm{PIj}$ and $\Delta \mathrm{DIj}$, which refer to the average score regarding the Presentation requirements (Sections 3-7) and the Disclosure requirements (Sections 8-32), respectively.

\section{Results and discussion}

\subsection{Descriptive statistics}

Table 4 shows the descriptive statistics of the variables $\Delta \mathrm{PIj}, \Delta \mathrm{DIj}$ and $\Delta \mathrm{PDIj}$ per section of the standard. The discussion of the most relevant results is divided into two subsections: presentation requirements and disclosure requirements. 
Table 4. Descriptive statistics

\begin{tabular}{|c|c|c|c|c|c|c|}
\hline & $\begin{array}{l}\text { Section of the IFRS for } \\
\text { SMEs }\end{array}$ & Mean & Variance & Min & Max & $\mathbf{N}$ \\
\hline 3 & $\begin{array}{ll}\text { Financial } & \text { Statement } \\
\text { Presentation } & \end{array}$ & 0.35785 & 0.00140 & 0.29167 & 0.47826 & 105 \\
\hline 4 & $\begin{array}{l}\text { Statement of Financial } \\
\text { Position }\end{array}$ & 0.43939 & 0.00100 & 0.39535 & 0.61111 & 105 \\
\hline 5 & $\begin{array}{l}\text { Statement of Comprehensive } \\
\text { Income and I.S. }\end{array}$ & 0.74228 & 0.00074 & 0.55556 & 0.76471 & 105 \\
\hline 6 & $\begin{array}{l}\text { Statement of Changes in } \\
\text { Equity }\end{array}$ & 0.80683 & 0.00482 & 0.66667 & 1.00000 & 98 \\
\hline 7 & Statement of Cash Flows & 0.57143 & 0.01077 & 0.42857 & 0.71429 & 19 \\
\hline$\Delta \mathbf{P I j}$ & Presentation requirements & 0.586366 & 0.000718 & 0.533557 & 0.671930 & \\
\hline 8 & $\begin{array}{l}\text { Notes to the Financial } \\
\text { Statements }\end{array}$ & 0.25181 & 0.00010 & 0.25000 & 0.33333 & 105 \\
\hline 10 & $\begin{array}{l}\text { Accounting Policies, } \\
\text { Estimates and Errors }\end{array}$ & 0.41667 & 0.12500 & 0.16667 & 0.66667 & 2 \\
\hline 11 & Basic Financial Instruments & 0.90892 & 0.00589 & 0.63636 & 1.00000 & 105 \\
\hline 12 & $\begin{array}{l}\text { Other Financial Instruments } \\
\text { Issues }\end{array}$ & 0.68611 & 0.00451 & 0.55556 & 0.80000 & 8 \\
\hline 13 & Inventories & 0.02041 & 0.00370 & 0.00000 & 0.20000 & 98 \\
\hline 14 & Investments in Associates & 0.10513 & 0.01451 & 0.00000 & 0.25000 & 13 \\
\hline 15 & Investments in Joint Ventures & 0.00000 & 0.00000 & 0.00000 & 0.00000 & 2 \\
\hline 17 & $\begin{array}{l}\text { Property, Plant and } \\
\text { Equipment }\end{array}$ & 0.32577 & 0.00924 & 0.16667 & 0.54545 & 102 \\
\hline 18 & $\begin{array}{l}\text { Intangible Assets other than } \\
\text { Goodwill }\end{array}$ & 0.45440 & 0.00544 & 0.33333 & 0.66667 & 94 \\
\hline
\end{tabular}




\begin{tabular}{|c|c|c|c|c|c|c|}
\hline 20 & Leases & 0.48333 & 0.11613 & 0.00000 & 0.83333 & 33 \\
\hline 21 & Provisions and Contingencies & 0.59747 & 0.01825 & 0.33333 & 0.80000 & 74 \\
\hline 23 & Revenue & 0.20263 & 0.00495 & 0.11111 & 0.50000 & 105 \\
\hline 24 & Government Grants & 0.00000 & 0.00000 & 0.00000 & 0.00000 & 40 \\
\hline 25 & Borrowing Costs & 0.48558 & 0.00707 & 0.00000 & 0.50000 & 104 \\
\hline 27 & Impairment of Assets & 0.00966 & 0.00317 & 0.00000 & 0.33333 & 69 \\
\hline 29 & Income Tax & 0.51292 & 0.01701 & 0.30000 & 0.81818 & 104 \\
\hline 30 & Foreign Currency Translation & 0.02688 & 0.01202 & 0.00000 & 0.66667 & 62 \\
\hline 32 & $\begin{array}{l}\text { Events after the End of the } \\
\text { Reporting Period }\end{array}$ & 0.32524 & 0.00138 & 0.16667 & 0.40000 & 105 \\
\hline$\Delta \mathrm{DIj}$ & Disclosure requirements & 0.355270 & 0.002998 & 0.263510 & 0.513889 & \\
\hline$\Delta$ PDIj & $\begin{array}{l}\text { Presentation and disclosure } \\
\text { requirements }\end{array}$ & 0.415920 & 0.001881 & 0.342903 & 0.537472 & \\
\hline
\end{tabular}

Presentation requirements. The highest levels of difference for the presentation requirements concern Sections 5 and 6, indicating that the content of these sections represents the most critical areas related to the divergences between the IFRS for SMEs presentation requirements and the Italian national model.

Section 5 Statement of Comprehensive Income and Income Statement includes a number of divergences, hence a high score (0.74). First, the components of comprehensive income are not presented by any entity (either presenting a single statement or double statement approach). This evidence is not surprising, because the Italian national model is based on the concept of "realised income" rather than "comprehensive income". Second, the IFRS for SMEs requires a classification of expenses based on either their nature or their function within the entity, whichever provides information that is reliable and more relevant. This prescription is not aligned with the Italian financial reporting practices, which are compliant with the classification by nature required by the national rules. Third, under the IFRS for SMEs, the presentation of extraordinary income and expenses is not allowed, nor is their description allowed in the notes. The Italian accounting model, conversely, prescribes both the presentation of such items in a specific section of the income statement (i.e., E) Extraordinary income and expenses) and their description in the notes, if relevant (art. 2427).

Another critical score (0.81) concerns Section 6 Statement of Changes in Equity and 
Statement of Income and Retained Earnings. Despite this document is not required by Italian regulations, some companies present it on a voluntary basis. In these latter cases, however, the reporting practices significantly differ from the IFRS for SMEs requirements because the only alignment retrieved concerns the reconciliation between the carrying amount at the beginning and the end of the period, for each component of equity, separately disclosing changes resulting from profit and loss. None of the other requirements fit the companies' practices perfectly.

An intermediate score (0.44) is obtained for Section 4 Statement of financial position. The most relevant divergence concerns the classification of assets and liabilities because the current/non-distinction and the order of liquidity are not aligned with the rigid schema prescribed by the Italian civil code. Additionally, it has been noted that many entities with shared capital do not disclose, either in their statements of financial position or in their notes, certain information about shares required by the IFRS for SMEs (e.g., number of shares authorised, number of shares issued and fully paid, etc.). Finally, another requirement not always satisfied concerns the description of the nature and purpose of each reserve within equity. A similar score (0.57) pertains to Section 7 Statement of Cash Flows. These statements, voluntarily prepared by the minority of companies, are presented as a note to the financial statement or as an annex. This practice is in contrast with the IFRS for SMEs, which requires entities to present each financial statement with equal prominence ${ }^{2}$.

Disclosure requirements. Sections 11, 12 and 21 present the highest levels of difference with the disclosure requirements.

The highest score assigned (0.91) pertains to Section 11 Basic Financial Instruments. The only requirement that matches the reporting practices is the disclosure of the measurement basis (or bases) used for financial instruments and the other accounting policies that are relevant to an understanding of the financial statements. The remaining requirements are not aligned with disclosure practices because the evaluation criteria provided by the IFRS for SMEs (i.e., fair value, amortised cost) are not allowed by the Italian accounting regulations for financial instruments.

Similar considerations can be made regarding Section 12 Other Financial Instruments Issues (0.69). Companies are used to disclosing descriptions of the hedge and the nature of the risks being hedged, but there is a lack of certain information, such as the periods when the cash flows are expected to occur and when they are expected to affect profit or loss.

Divergences have also been detected in Section 21 Provisions and Contingencies (0.60). Specifically, Italian reporting practices seem to avoid the disclosure of some information in the notes, such as the carrying amounts, additions and adjustments for each class of provision reported in the statement of financial position.

In contrast, Sections 15 Investments in Joint Ventures and 24 Government Grants have null levels of difference (0), indicating that the disclosure practices of those topics are perfectly aligned with the IFRS for SMEs requirements.

${ }^{2}$ IASB, IFRS for SMEs, London, UK, 2009, Section 3, par. 3.21. 


\section{Macrothink \\ International Journal of Accounting and Financial Reporting \\ ISSN 2162-3082 \\ 2016, Vol. 6, No. 2}

\subsection{Econometric Analysis}

To empirically test the hypotheses formulated in Section 2, we ran a stepwise OLS regression, considering the correlation matrix of our variables (Table 5). This method optimises the econometric model by excluding all statistically non-significant variables from the model. This approach is considered to be appropriate for exploratory analysis and has been adopted to investigate the determinants of differences between domestic and international accounting standards (Ding et al., 2007). In our study, we consider the $\triangle P D I_{j}$ as the main dependent variable, which is further broken down into two dependent sub-variables, $\triangle P I_{j}$ and $\Delta D I_{j}$, which refer to the average score of the Presentation requirements (Sections 37) and Disclosure requirements (Sections 8-32), respectively.

Table 5. Correlation matrix of dependent and independent variables

$\triangle \mathrm{PDI} \quad \triangle \mathrm{PI} \quad \Delta \mathrm{DI} \quad$ ASSETS EBT/ LEV $\quad$ BIG4 IFRS

SALES

GROUP

$\triangle \mathrm{PDI}$

1.000000

$\Delta \mathrm{PI}$

0.1168231 .000000

$\Delta \mathrm{DI}$

0.9690700 .0791481 .000000

ASSETS

0.2113630 .0962660 .0791481 .000000

EBT/SALE -

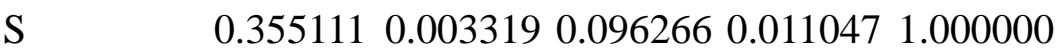

LEV

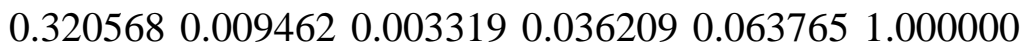

BIG4

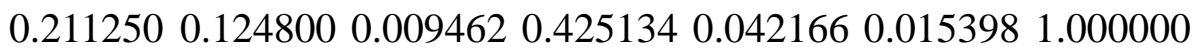

IFRS_GRO -

$\begin{array}{lllllllll}\text { UP } & 0.180437 & 0.119551 & 0.124800 & 0.536335 & 0.070355 & 0.039377 & 0.579526 & 1.000000\end{array}$

Following the stepwise procedure, the independent variable most correlated with the 


\section{Macrothink}

International Journal of Accounting and Financial Reporting

ISSN 2162-3082

dependent variable was introduced in the model, followed by the other independent variables included one by one, on the basis of the partial correlation coefficients. Two models yielded satisfactory results (Table 6).

The first model considers $\triangle P D I$ as the dependent variable, i.e., the average score of both the Presentation and Disclosure requirements. Significant results were obtained for the following variables: EBT/SALES, $L E V$ and ASSETS. Together, they explain $36.6 \%$ of the total variance of the $\triangle P D I$. However, the coefficients of EBT/SALES and ASSETS are negative and significant at the $1 \%$ level, whereas the coefficient of $L E V$ has a positive sign and is significant at the 5\% level. The inclusion of BIG4 and IFRS_GROUP as additional independent variables did not improve the model.

The second model considers $\triangle D I$ as the dependent variable, i.e., the average score of Disclosure requirements. EBT/SALES, LEV and IFRS_GROUP gave significant results and explain $24.7 \%$ of the total variance of the $\triangle D I$. Again, two variables have negative influences (EBT/SALES and IFRS_GROUP, significant at $1 \%$ and 5\%, respectively), whereas LEV confirms its positive sign with a significance level of $1 \%$. The inclusion of BIG4 and ASSETS as additional independent variables was not significant.

Table 6. OLS regression models

\section{Dependent Variable: $\triangle P D I$}

\begin{tabular}{|c|c|c|c|c|}
\hline Variable & Coefficient & Std. Error & t-Statistic & Prob. \\
\hline $\mathrm{C}$ & 0.526358 & 0.026954 & 19.52829 & 0.0000 \\
\hline EBT/SALES & -0.012577 & 0.003750 & -3.353729 & 0.0011 \\
\hline$L E V$ & 0.017390 & 0.007416 & 2.344965 & 0.0210 \\
\hline \multirow[t]{3}{*}{ ASSETS } & -0.007949 & 0.001525 & -5.213774 & 0.0000 \\
\hline & $\begin{array}{l}\text { S.E. } \\
\text { regression }\end{array}$ & $\begin{array}{l}\text { of Sum squared } \\
\text { resid }\end{array}$ & F-statistic & $\begin{array}{l}\text { Prob } \\
\text { statistic) }\end{array}$ \\
\hline & 0.032218 & 0.102761 & 20.59645 & 0.000000 \\
\hline \multicolumn{5}{|l|}{ R-squared $=0.384288$} \\
\hline Adjusted R-squared $=0.365630$ & & & & \\
\hline
\end{tabular}




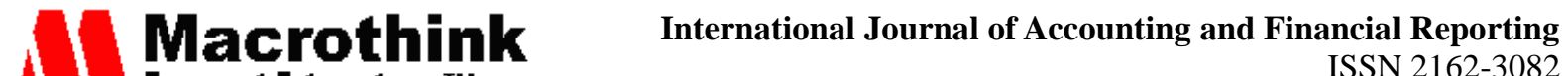

\section{Dependent Variable: $\Delta D I$}

\begin{tabular}{llccc}
\hline Variable & Coefficient & Std. Error & t-Statistic & Prob. \\
C & 0.328089 & 0.008536 & 38.43599 & 0.0000 \\
EBT/SALES & -0.019367 & 0.005081 & -3.811400 & 0.0002 \\
LEV & 0.034931 & 0.009834 & 3.551901 & 0.0006 \\
IFRS_GROUP & -0.039823 & 0.015447 & -2.578116 & 0.0114 \\
\hline & S.E. & of Sum squared & F-statistic & Prob \\
& regression & resid & & statistic) \\
& & & & \\
& 0.044117 & 0.192681 & 12.15242 & 0.000001 \\
R-squared $=0.269142$ & & & & \\
Adjusted R-squared $=0.246995$ & & & & \\
\hline \hline
\end{tabular}

In summary, the econometric analysis suggests that the firms with greater differences with the IFRS for SMEs presentation and disclosure requirements are likely to be: a) less profitable as measured by EBT/Total sales; b) more leveraged as measured by Liabilities/Total assets; c) small in size as measured by Total assets; and d) not influenced by their parent companies as not included in their IFRS-compliant consolidated annual report.

Concerning the negative influence of profitability, it should be noted that this factor is not measured as a ratio of profit before tax to net assets (or outstanding equity) but rather as a ratio of profit before tax divided by sales. Although the former involves the overall performance of a business, the latter involves a corporation's capacity to absorb rising costs. An interpretation of this result is that less profitable firms are likely to have limited or null engagement in international trade activities, hence a greater difference between local-driven disclosure practices and international-oriented accounting requirements.

The positive and significant association between differences in disclosure and leverage (measured as Liabilities/Total assets) is not surprising. Indeed, our concern regarded the different recipients of the IFRS for SMEs and the Italian domestic model: users in their decision-making processes vs. creditors, respectively. Empirical results demonstrate that more leveraged firms provide information closer to creditor needs, in contrast to the IFRS for SMEs requirements. This finding enriches the role of shareholders' and creditors' protection by the legal systems as a relevant institutional factor to be considered in accounting studies (Houqe et al., 2012; Jaggi \& Low, 2000; La Porta et al., 1998; La Porta et al., 2000). 


\section{MInstitute Macrothink $_{\text {Int }}$}

International Journal of Accounting and Financial Reporting

ISSN 2162-3082

2016, Vol. 6, No. 2

Some caution concerns corporate size. Its negative and significant influence has the lowest coefficient among the explanatory variables, and it is detected only when considering the $\triangle$ PDI. However, this result seems to be consistent with Eierle \& Haller (2009), in which corporate size has been found to influence the suitability of the IFRS for SMEs in a similar context, i.e., German SMEs.

Finally, our expectations about parent company influence have been empirically confirmed. Italian SMEs included in consolidated IFRS-based financial statements perceive their parent company influences with regard to information to be disclosed. The main implication of this result is that it would be more suitable for these companies to adopt IFRS for SMEs for their individual annual accounts. This finding is also in agreement with Alexander (2015) in suggesting that strong practical cost-based incentives for harmonisation between the IFRS consolidated statements and individual company statements are needed.

\section{Conclusions, Limitations and Future Research}

This paper provides a comprehensive comparison of the IFRS for SMEs presentation and disclosure requirements with the Italian domestic reporting practices. The main results concern the major differences existing in the presentation of financial statements, as well as in narrative disclosure practices in management commentary and notes. It also draws on previous research to identify certain corporate attributes that affect the extent of differences with the IFRS for SMEs presentation and disclosure requirements.

This study indicates a number of implications for several subjects, including regulators, preparers and academics. Regulators could receive feedback regarding possible adoption of the IFRS for SMEs, for which useful suggestions on adoption scenarios and consequences could be derived. In particular, specific critical areas that would require financial regulatory accommodation have been identified. Preparers - both SMEs and their financial advisors could receive a preliminary overview of the practical challenges deriving from the possible future adoption of the standard. Academics could benefit from new empirical evidence within the ongoing IFRS for SMEs debate, specifically regarding presentation and disclosure requirements.

However, there are some limitations of this study. First, the IASB's Comprehensive review of the IFRS for SMEs is not considered. Such a review was planned to consider whether there was a need for any amendments. However, the IASB has made limited amendments to the IFRS for SMEs, aiming to clarify the existing requirements or to add supporting guidance, rather than to change the underlying requirements of the IFRS for SMEs. The most significant amendments are: permitting SMEs to use a revaluation model for property, plant and equipment; and aligning the main recognition and measurement requirements for deferred income tax with the IFRS. Second, the future effects of European Directive 2013/34/EU on the annual financial statements are not considered. This new regulation attempts both to simplify SMEs accounting regulation and to promote their internationalization. In this regard, the new Directive introduces certain issues closer to the IAS/IFRS model, e.g., the introduction of fair value for recognition and measurement of financial instruments; the introduction of revalued amounts as an alternative measurement 
basis for fixed assets; and the distinction between current and non-current items as an alternative presentation of the balance sheet . Third, this study is limited to the manufacturing sector. Although manufacturing is the most representative activity of SMEs, perhaps some results might have been different if different industrial sectors had been studied.

Future research should extend this work to other sectors and jurisdictions to compare different contexts and to suggest appropriate strategies for the adoption of the standard. Nonaccounting-based exploratory factors could also be considered, such as those related to corporate governance (e.g., the presence of outside directors, number of shareholders) and reporting effectiveness (e.g., timeliness, cost of preparation). Finally, compliance with the IFRS for SMEs presentation and disclosure requirements could be assessed within the context of first-time adoption, as well as comparing pre- and post-adoption of the standard.

\section{References}

Aboagye-Otchere, F., \& Agbeibor, J. (2012). The International Financial Reporting Standard for Small and Medium-sized Entities (IFRS for SMES): Suitability for small businesses in Ghana. Journal of Financial Reporting and Accounting, 10(2), 190-214. http://dx.doi.org/10.1108/19852511211273723

Ahmed, K., \& Courtis, J. K. (1999). Associations between corporate characteristics and disclosure levels in annual reports: a meta-analysis. The British Accounting Review, 31(1), 35-61. http://dx.doi.org/10.1006/bare.1998.0082

Al-Akra, M., Eddie, I. A., \& Ali, M. J. (2010). The influence of the introduction of accounting disclosure regulation on mandatory disclosure compliance: Evidence from Jordan. The British Accounting Review, 42(3), 170-186. http://dx.doi.org/10.1016/j.bar.2010.04.001

Albu, C. N., Albu, N., \& Fekete, S. (2010). The Context of the Possible IFRS for SMEs Implementation in Romania: An Exploratory Study. Accounting and Management Information Systems, 9(1), 45-71.

Albu, C. N., Albu, N., Pali-Pista, S. F., Gîrbină, M. M., Selimoglu, S. K., Kovács, D. M., Lukács, J., Mohl, G., Müllerová, L., Paseková, M., Arsoy, A. P., Sipahi, B., \& Strouhal, J. (2013). Implementation of IFRS for SMEs in Emerging Economies: Stakeholder Perceptions in the Czech Republic, Hungary, Romania and Turkey. Journal of International Financial Management \& Accounting, 24, 140-175. 140-175. http://dx.doi.org/10.1111/jifm.12008

Alexander, D. (2015). Directive 2013/34/EU, Article 6 An Analysis and some Implications. A Research Note. Financial Reporting, (1), 5-22. http://dx.doi.org/10.3280/FR2015-001001

Alver, L., Alver, J., \& Talpas, L. (2014). Implementation of IFRSs and IFRS for SMEs: the case of Estonia. Accounting and Management Information Systems, 13(2), 236-258.

Arsoy, A. P., Sipahi, B., Üniversitesi, U., \& Üniversitesi, M. (2007). International Financial Reporting Standards X for Small And Medium Sized Entities And The Turkish Case. Ankara Üniversitesi SBF Dergisi, c, 62. 


\section{MInstitute Macrothink $_{\text {Int }}$}

International Journal of Accounting and Financial Reporting ISSN 2162-3082

Atik, A. (2010). SME's Views on the Adoption and Application of "IFRS for SMEs" in Turkey. European Research Studies Journal, 13(4), 19-32.

Baldarelli, M. G., Demartini, P., \& Mošnja-Škare, L. (2007). International Accounting Standards for SMEs. Piccola Impresa/Small Business, 20(1), 53-73.

Ball, R., Kothari, S. P., \& Robin, A. (2000). The effect of international institutional factors on properties of accounting earnings. Journal of accounting and economics, 29(1), 1-51. http://dx.doi.org/10.1016/S0165-4101(00)00012-4

Buculescu, M. M., \& Velicescu, B. N. (2014). An Analysis of the Convergence Level of Tangible Assets (PPE) According to Romanian National Accounting Regulation and IFRS for Smes. Accounting and Management Information Systems, 13(4), 774-799.

Buzby, S. L. (1975). Company Size, Listed Versus Unlisted Stocks, and the Extent of Financial Disclosure. Journal of Accounting Research, 13(1), 16-37. http://dx.doi.org/10.2307/2490647

Chow, C. W., \& Wong-Boren, A. (1987). Voluntary financial disclosure by Mexican corporations. The Accounting Review, 62(3), 533-541.

Cisi, M. (2008). L'evoluzione del bilancio delle società non quotate. Codice civile o IFRS?. Milano: Giuffrè.

Cooke, T. (1989). Voluntary corporate disclosure by Swedish companies'. Journal of International Financial Management \& Accounting, 1(2), 113-124. http://dx.doi.org/0.1111/j.1467-646X.1989.tb00009.x

Cooke, T. E. (1992). The Impact of Size, Stock Market Listing and Industry Type on Disclosure in the Annual Reports of Japanese Listed Corporations. Accounting and Business Research, 22(87), 229-237. http://dx.doi.org/10.1080/00014788.1992.9729440

Di Pietra, R., Evans, L., Chevy, J., Cisi, M., Eierle, B., Jarvis, R., \& On Behalf Of The European Accounting Association's Financial Reporting Standards Committee (2008). Comment on the IASB's Exposure Draft 'IFRS for Small and Medium-Sized Entities'. Accounting in Europe, 5(1), 27-47. http://dx.doi.org /10.1080/17449480802049392

Ding, Y., Hope, O.-K., Jeanjean, T., \& Stolowy, H. (2007). Differences between domestic accounting standards and IAS: Measurement, determinants and implications. Journal of $\begin{array}{lllll}\text { Accounting } \quad \text { and Public } & \text { Policy, }\end{array}$ http://dx.doi.org/10.1016/j.jaccpubpol.2006.11.001

Dunne, T., Fifield, S., Finningham, G., Fox, A., Hannah, G., Helliar, C., Power, D., \& Veneziani, M. (2008). The implementation of IFRS in the UK, Italy, and Ireland. Edinburgh: The Institute of Chartered Accountants of Scotland.

EFAA (2010). Comparison of IFRS for SMEs and national GAAP of nine European countries. London: Association of Chartered Certified Accountants.

EFRAG (2010). IFRS for SMEs and the Fourth and Seventh Council Directives. 
Compatibility Issues.

Eierle, B., \& Haller, A. (2009). Does Size Influence the Suitability of the IFRS for Small and Medium-Sized Entities? - Empirical Evidence from Germany. Accounting in Europe, 6(2), 195-230. http://dx.doi.org/10.1080/17449480903115779

El-Gazzar, S. M., Finn, P. M., \& Jacob, R. (1999). An empirical investigation of multinational firms' compliance with International Accounting Standards. The International Journal of Accounting, 34(2), 239-248. http://dx.doi.org/10.1016/S0020-7063(99)00005-9

Evans, L., Gebhardt, G., Hoogendoorn, M., Marton, J., Di Pietra, R., Mora, A., Thinggård, F., Vehmanen, P., \& Wagenhofer, A. (2005). Problems and Opportunities of an International Financial Reporting Standard for Small and Medium-sized Entities. The EAA FRSC's Comment on the IASB's Discussion Paper. Accounting in Europe, 2(1), 23-45. http://dx.doi.org/10.1080/09638180500378949

Gîrbină, M. M., Albu, C. N., \& Albu, N. (2012). Convergence of National Regulations with IFRS for SMEs: Empirical Evidences in the Case of Romania. International Journal of Social, Human Science and Engineering, 6(9), 19-23.

Houqe, M. N., van Zijl, T., Dunstan, K., \& Karim, A. K. M. W. (2012). The Effect of IFRS Adoption and Investor Protection on Earnings Quality Around the World. International Journal of Accounting, 47(3), 333-355. http://dx.doi.org/10.1016/j.intacc.2012.07.003

IASB (2009). IFRS for SMEs. London, UK.

Jaggi, B., \& Low, P. Y. (2000). Impact of culture, market forces, and legal system on financial disclosures. The International Journal of Accounting, 35(4), 495-519. http://dx.doi.org/10.1016/S0020-7063(00)00076-5

Jensen, M. C., \& Meckling, W. H. (1976). Theory of the firm: Managerial behavior, agency costs and ownership structure. Journal of Financial Economics, 3(4), 305-360. http://dx.doi.org/10.1016/0304-405X(76)90026-X

Jermakowicz, E. K., \& Epstein, B. J. (2010). IFRS for SMEs-An Option for US Private Entities? Review of Business, 30(2), 72-79.

Jerman, M., \& Ivankovič, G. (2011). The evolution of financial standards for Small and Medium-sized Entities. Scientific Annals of the'Alexandru Ioan Cuza'University of Iasi: Economic Sciences Series, 13-24.

Kaufhold, G. (2015). Compatibility of the IFRS for Small and Medium-sized Entities and the new EU-Accounting Directive. Acta Universitatis Agriculturae et Silviculturae Mendelianae Brunensis, 63(6), 1945-1951. http://dx.doi.org/10.11118/actaun201563061945

Kaya, D., \& Koch, M. (2015). Countries' adoption of the International Financial Reporting Standard for Small and Medium-sized Entities (IFRS for SMEs) - early empirical evidence. $\begin{array}{lllr}\text { Accounting and Business } & \text { Research, 45(1), }\end{array}$ http://dx.doi.org/10.1080/00014788.2014.969188 


\section{Mll Macrothink}

International Journal of Accounting and Financial Reporting ISSN 2162-3082 2016, Vol. 6, No. 2

Kiliç, M., Uyar, A., \& Ataman, B. (2016). Preparedness of the entities for the IFRS for SMEs: an emerging country case. Journal of Accounting in Emerging Economies, 6(2), 156-178. http://dx.doi.org/10.1108/JAEE-01-2014-0003

Kreipl, M., Hane, T., \& Mueller, S. (2014). Information Quality under IFRS, IFRS for SME and German-GAAP-Survey on Preferences of Non-Publicly Traded Mid-Sized Corporations. Open Journal of Business and Management, April(2), 138-150. http://dx.doi.org/10.4236/ojbm.2014.22017

Kumar, V. (2014). Readiness of SMEs in UAE for an accounting standard transition to IFRS for SMEs: an empirical analysis. International Journal of Strategic Business Alliances, 3(4), 282-296. http://dx.doi.org/10.1504/IJSBA.2014.067145

La Porta, R., Lopez-de-Silanes, F., Shleifer, A., \& Vishny, R. (2000). Investor protection and corporate governance. Journal of Financial Economics, 58(1-2), 3-27. http://dx.doi.org/10.1016/S0304-405X(00)00065-9

La Porta, R., Lopez de Silanes, F., Shleifer, A., \& Vishny, Robert W. (1998). Law and Finance. Journal of Political Economy, 106(6), 1113-1155. 1113-1155. http://dx.doi.org/10.1086/250042

Larson, R. K., \& Street, D. L. (2004). Convergence with IFRS in an expanding Europe: progress and obstacles identified by large accounting firms' survey. Journal of International $\begin{array}{llll}\text { Accounting, Auditing } \quad \text { and } & \text { 89xation, } 119 \text {. }\end{array}$ http://dx.doi.org/10.1016/j.intaccaudtax.2004.09.002

Litjens, R., Bissessur, S., Langendijk, H., \& Vergoossen, R. (2012). How do preparers perceive costs and benefits of IFRS for SMEs? Empirical evidence from the Netherlands. Accounting in Europe, 9(2), 227-250. http://dx.doi.org/10.1080/17449480.2012.720875

Mandilas, A., Nikolaidis, M., Valsamidis, S., \& Nikolaidis, A. (2010). An Empirical Study on the Adoption of IFRS for SMEs: the Case of Kavala, Greece. MIBES (Management of International Business and Economics Systems Conference), pp. 409-432. Kavala, Greece.

Milanés Montero, P., Albarrán Lozano, I., Texeira Quirós, J., \& Pérez Calderón, E. (2011). Accounting standards for small and medium-sized entities. Evidence from Spain. Contaduría y Administración, 235(sep-dic), 29-55.

Nerudova, D., \& Bohusova, H. (2008). The empirical study of the SMEs position in the process of IFRS for SMEs application in the Czech Republic. Economics \& Management, 13, 163-169.

Nobes, C. W. (2009). Observations on measuring the differences between domestic accounting standards and IAS. Journal of Accounting and Public Policy, 28(2), 148-153. http://dx.doi.org/10.1016/j.jaccpubpol.2009.01.003

Owusu-Ansah, S. (1998). The impact of corporate attribites on the extent of mandatory disclosure and reporting by listed companies in Zimbabwe. The International Journal of Accounting, 33(5), 605-631. http://dx.doi.org/10.1016/S0020-7063(98)90015-2 


\section{Macrothink}

International Journal of Accounting and Financial Reporting ISSN 2162-3082 2016, Vol. 6, No. 2

Pacter, P. (2009). An IFRS for private entities. International Journal of Disclosure and Governance, 6(1), 4-20. http://dx.doi.org/10.1057/jdg.2008.24

Pacter, P. (2013). The IFRS for SMEs. In C. van Mourik \& P. Walton (Eds.), The Routledge Companion to Accounting, Reporting and Regulation (pp. 411-434). Abingdon, Oxon RN: Taylor \& Francis.

Pàlka, P., \& Svitàkovà, B. (2011). Impact of IFRS for SMEs Adoption on Performance of Czech Companies. In J. Strouhal (Ed.), Recent Researches In Economics And Management Transformation (pp. 49-54). Angers, France: WSEAS Press.

Patton, J., \& Zelenka, I. (1997). An empirical analysis of the determinants of the extent of disclosure in annual reports of joint stock companies in the Czech Republic. European Accounting Review, 6(4), 605-626. http://dx.doi.org/10.1080/09638189700000003

PWC. (2009). Similarities and differences - A comparison of "full IFRS" and IFRS for SMEs. Wolters Kluwer.

Quagli, A., \& Paoloni, P. (2012). How is the IFRS for SME accepted in the European context? An analysis of the homogeneity among European countries, users and preparers in the European commission questionnaire. Advances in Accounting, 28(1), 147-156. http://dx.doi.org/10.1016/j.adiac.2012.03.003

Raffournier, B. (1995). The determinants of voluntary financial disclosure by Swiss listed companies. European Accounting Review, 4(2), 261-280. http://dx.doi.org/10.1080/09638189500000016

Salter, S. B., \& Doupnik, T. S. (1992). The relationship between legal systems and accounting practices: a classification exercise. Advances in International Accounting, 5(1), 3-22.

Schutte, D. P., \& Buys, P. (2011). A critical analysis of the contents of the IFRS for SMEs - a South African perspective. South African Journal of Economic and Management Sciences, 14(2), 188-209.

Singhvi, S. S., \& Desai, H. B. (1971). An Empirical Analysis of the Quality of Corporate Financial Disclosure. The Accounting Review, 46(1), 129-138.

Soderstrom, N. S., \& Sun, K. J. (2007). IFRS Adoption and Accounting Quality: A Review. European Accounting Review, 16(4), 675-702. http://dx.doi.org/10.1080/09638180701706732

Stainbank, L. (2008). The Development of Financial Reporting for SMEs in South Africa: Implications of Recent and Impending Changes. African Journal of Accounting, Economics, Finance \& Banking Research, 3(3), 1-17.

Street, D. L., \& Bryant, S. M. (2000). Disclosure Level and Compliance with IASs: A Comparison of Companies With and Without U.S. Listings and Filings. The International Journal of Accounting, 35(3), 305-329. http://dx.doi.org/10.1016/S0020-7063(00)00060-1

Street, D. L., \& Gray, S. J. (2002). Factors influencing the extent of corporate compliance 


\section{Macrothink}

International Journal of Accounting and Financial Reporting

ISSN 2162-3082 2016, Vol. 6, No. 2

with International Accounting Standards: summary of a research monograph. Journal of International Accounting, Auditing and Taxation, 11(1), 51-76. http://dx.doi.org/10.1016/S1061-9518(02)00054-X

Strouhal, J., Müllerová, L., Cardová, Z., \& Paseková, M. (2009). National and international financial reporting rules: Testing the compatibility of Czech reporting from the SMEs perspective. WSEAS Transactions on Business and Economics, 6, 620-629.

Tower, G., Hancock, P., \& Taplin, R. H. (1999). A Regional Study Of Listed Companies' Compliance with International Accounting Standards. Accounting Forum, 23(3), 293-305. http://dx.doi.org/10.1111/1467-6303.00016

Turegun, N., \& Kaya, C. T. (2014). Repeated Cross Sectional Analysis of Acuity of Turkish CPAs on the Adoption of IFRS for SMEs for Turkish SMEs. Research Journal of Finance and Accounting, 5(3), 49-55.

van Wyk, H. A., \& Rossouw, J. (2009). IFRS for SMEs in South Africa: a giant leap for accounting, but too big for smaller entities in general. Meditari Accountancy Research, 17(1), 99-116. http://dx.doi.org/10.1108/10222529200900007

Wallace, R. S. O., \& Naser, K. (1995). Firm-specific determinants of the comprehensiveness of mandatory disclosure in the corporate annual reports of firms listed on the stock exchange of Hong Kong. Journal of Accounting and Public Policy, 14(4), 311-368. http://dx.doi.org/10.1016/0278-4254(95)00042-9

Wallace, R. S. O., Naser, K., \& Mora, A. (1994). The relationship between the comprehensiveness of corporate annual reports and firm characteristics in Spain. Accounting and Business Research, 25, 41-53, 10.1080/00014788.1994.9729927

\section{Copyright Disclaimer}

Copyright for this article is retained by the author(s), with first publication rights granted to the journal.

This is an open-access article distributed under the terms and conditions of the Creative Commons Attribution license (http://creativecommons.org/licenses/by/3.0/). 